\title{
Students' Self-Assessment of Arabic Speaking Skill
}

\author{
Matrokhim \\ IAIN Salatiga
}

Article History:

Received : 15 December 2021

Revised : 16 December 2021

Accepted : 16 December 2021

Published : 16 December 2021

Keywords:

Self-assessment, Arabic language, Speaking skill

*Correspondence Address: $\underline{\text { matrokhim125@iainsalatiga.ac.id }}$

\begin{abstract}
This study was aimed at determining students' selfassessment of their Arabic speaking skills. The data was gathered through distributing speaking rubric to 92 Arabic language learners. The rubric was adapted from Cherice Montgomery and was consisted of six aspects of speaking, namely pronunciation, fluency, vocabulary, content, accuracy, and comperehension and startegic competence. The data was analysed using Winstep to determine their self-assessment of speaking and how they perceive those six aspects of speaking skills. The result showed that the students identify their speaking performance as moderate level. The Wright Map revealed that content was the most difficult aspect of speaking, while pronunciation was the easiest aspect of it.
\end{abstract}

\section{A. INTRODUCTION}

Speaking, as one among four other communication skills, is known as a productive skill used as communication tool through oral form. Therefore, it has been emphasized in the objectives of learning foreign language such as English, Arabic and other languages in educational institution, for instance Salatiga State Islamic Institute for Islamic Studies (IAIN Salatiga). Students majoring in Arabic Education were taught about vocabularies, grammar, morphology, listening, muhadatsah etc. For those who take the muhadatsah course, the goal of learning is being able to speak Arabic language orally. ${ }^{1}$

Eaton added that the foreign language teaching and learning in the twentyfirst century is no longer focused on mastering the grammatical rules and memorizing vocabularies, but it is rather concernedabout how to use the target language as well as the cultural knowledge as a tool to communicate with people

${ }^{1}$ Kaharuddin, 'Pembelajaran Bahasa Arab Melalui Kemampuan Muhadatsah', AL-ISHLAH: Jurnal Pendidikan Islam, 16.1 (2018), 62-72. 
from all over the world ${ }^{2}$. Although speaking skill is considered as one of the important skills for the language learners, it doesn't mean that other skills was not important, because those four skills are very important in language learning.

As mentioned by Rahmawati and Ertin, assessment in the teaching and learning process is very important. ${ }^{3}$ The assessment itself can be done not only by the lecturers, but also by the students themselves. Students' self-assessment will let them take responsibility for being involved in and eventually make decision about it. ${ }^{4}$ Conducting Arabic speaking assessment would enable learners and lecturers to reflect on theirArabic learning process besides as well as enabling mutual feedback between them.

Ross also explained that self-assessment can contribute to students' selfefficacy through mastery and vicarious experiences. By assessing their own speaking ability, they would focus on particular aspects of their performance, redefine the standard they use to decide whether their performance good or not and reinforce positive reactions to the successful performance. ${ }^{5} \mathrm{Also}$, this experience of assessment would give them an insight about being a language teacher in the future who will assess their students' ability.

Assessing speaking skill is a difficult, time-consuming and complex task, however, it is highly demanded because speaking is the core of foreign language teaching and learning process. ${ }^{6}$ The self-assessment of speaking performance is conducted by asking the students to perform speaking task and record it, then they listen to their recording and assess it using the rubric.

The aspects of self-assessment have gained substantial attention in various educational contexts, including in foreign and second language education. Therefore, several studies on assessing speaking skills have been conducted 2010).

${ }^{2}$ Sarah Elaine Eaton, Global Trends in Language Learning in the 21st Century, Onate Press (Calgary,

${ }^{3}$ YennyRahmawati and Ertin, 'Developing Assessment for Speaking', Indonesian Journal of English Education, 1 (2014), 199-210.

${ }^{4}$ Leslie Dickinson, Self-Instruction in Language Learning, Angewandte Chemie International Edition, 6(11), 951-952. (Australia: Press Syndicate of the University of Cambridge, 1987).

5John A. Ross, 'The Reliability, Validity, and Utility of Self-Assessment', Practical Assessment, Research and Evaluation, 11.10 (2006).

${ }^{6}$ Rúben Constantino Correia, 'Assessing Speaking Proficiency: A Challenge for the Portuguese EFL Teacher', E-TEALS, 7.1 (2016). 
previously, for instance Ariafar and Fatemipour who carried out their study on the Effect of Self-Assessment on Iranian EFL Learners' Speaking Skill and found that self-assessment practices helped the students to improve their speaking ability. ${ }^{7}$ In line with the previous research, Butler and Jiyoon Lee also found that selfassessment helped students increase their confidence. ${ }^{8}$

Despite many previous research on self-assessment, not many of it that was aimed at investigating which aspect of speaking skills that that may hinder students' performance. Moreover, the results of the initial observations showed that the speaking skills of students IAIN Salatiga students were found to be still very low. These results were obtained from direct observation and dialogue using Arabic with students. Ideally, Arabic language students should have good skills in speaking Arabic since they have learnedthe linguistics aspect such as mufrodat, nahwu and sharaf.

This study was carried out to determine the students' self-assessment of speaking skills and how they perceive the six aspects of speaking skills so that both the students and the lecturers would have insight about it and design the strategy and classroom activities that can help the students to reach their learning goals.

\section{B. METHOD}

This survey research was carried out in the Arabic Education Department of Salatiga State Institute for Islamic Studies (IAIN Salatiga). This location was chosen because the researcher is the lecturer of the university who teach muhadatsah course. About 92 students has participated in this research. They were chosen purposively for being involved in Arabic speaking classes. They were asked to record their speaking activity then assess their speaking ability using rubric. The rubric used in this study was adapted from speaking self-assessment rubric by Cherice Montgomery in $2000 .^{9}$

${ }^{7}$ Mahsa Ariafar and Hamid Reza Fatemipour, 'The Effect of Self-Assessment on Iranian EFL Learners' Speaking Skill', International Journal of Applied Linguistics and English Literature, 2.4 (2013), 7-13.

${ }^{8}$ Yuko Goto Butler and Jiyoon Lee, 'The Effects of Self-Assessment among Young Learners of English', Language Testing, 27.1 (2010), 5-31.

${ }^{9}$ Cherice Montgomery, Speaking Rubric by Bill Heller, 2000. 
The instrument was developed to measure the students' speaking ability using 6 aspects, namely pronunciation, fluency, vocabulary, accuracy, content, and comprehension dan strategy competence. The students rated their ability from 1 to 4 . The higher they perceive their ability, the higher their ability.

Table 1. Summary statistics of self-assessment speaking rubric

\begin{tabular}{cccccc}
\hline & Mean & SD & Strata & Reliability & $\begin{array}{c}\text { Cronbach's } \\
\text { Alpha Value }\end{array}$ \\
\hline Person & $-1,07$ & 2,33 & 3,41 & 0,84 & 0,83 \\
Item & 0,00 & 1,27 & 5,45 & 0,94 & \\
\hline
\end{tabular}

The table above showed the summary statistics of the rubric. It described that the Cronbach alpha value of the rubric is 0.83 meaning that the overall interaction between respondents and items is highly reliable (Cohen et al., 2007). These data then analysed using IBM SPSS and Winstep from Rasch Analysis. Winstep was run to determine the students' level of self-assessment of their speaking ability and determine which aspect was the most difficult and easier aspect of speaking ability. The IBM SPSS was also used to determine whether there is difference in their speaking ability between male and female students.

\section{RESULT AND DISCUSSION}

\section{Students' Demography}

About 92 university students have participated in this study. The following table described their personal background:

Table 2. Students' Demographic Background

\begin{tabular}{llll}
\hline \multicolumn{2}{c}{ Demographic } & N & $\%$ \\
\hline Gender & Male & 26 & $28 \%$ \\
\cline { 2 - 4 } & Female & 66 & $72 \%$ \\
\hline Experience Living in Pondok & Yes & 64 & $70 \%$ \\
\cline { 2 - 4 } & No & 28 & $30 \%$ \\
\hline
\end{tabular}


According to table above, there are 26 male students (28\%) and 66 female students $(72 \%)$ who attend the muhadatsah class this semester and are involved in this study. Meaning that most of the respondents in this study are female students.

As shown in the Table 2, approximately $70 \%$ of the participants are those who have experienced living in pondok and learned Arabic before attending university. While $30 \%$ of them are those who just started learning Arabic in the university. This demographic background was used to determine the difference in their speaking anxiety according to it.

\section{Students' Self-Assessment of Speaking Ability}

Giving the students a chance to assess their own ability gives them positive impact, especially in terms of their independency on teacher and classroom ${ }^{10}$. Besides, they can identify their own performance whether it is good or not, their weakness and their strength. Then, they would know what should they do to improve their speaking ability. This can also help them improve their motivation in language learning. ${ }^{11}$ Therefore, there is a high demand to involve the students in assessing their learning achievement, for example assessing their own speaking skill.

The adapted version of Self-Assessment Speaking Rubric was given to the students of Arabic Education Department who attend the muhadatsahclass. The data was then analyzed using Winstep to get the Wright Map and the logit measure to determine the students' self-assessment of their Arabic speaking ability.

Table 3. Students' Level of Self-Assessment Arabic Speaking Ability

\begin{tabular}{cccc}
\hline Logit Score & $\begin{array}{c}\text { Number of } \\
\text { Students }\end{array}$ & Percentage & Level \\
\hline$>1.39$ & 12 & $12 \%$ & High \\
\hline 1.39 to -3.11 & 65 & $71 \%$ & Moderate \\
\hline$<-3.11$ & 15 & $16 \%$ & Low \\
\hline
\end{tabular}

${ }^{10}$ Gita Mutiara Hati, Wisma Yunita, and Anggun Citra Sari Dewi, 'Self Assessment for Higher Language Learners' Autonomy', JOALL (Journal of Applied Linguistics and Literature), 6.2 (2021).

${ }^{11}$ Asdar, 'Students' Self -Assessment on Their Spoken Interaction Using Cefr', The 1st Education and Language International Conference Proceedings Center for International Language Development of Unissula (2017). 
The Table 3 showed the logit measure from all participants of this survey research. Approximately 92 students are categorized into 3 different level of selfassessment of speaking ability, namely high, moderate and low level of speaking ability. The cut-off point in this map is the value mean -,86 and standard deviation 2,25 of the logit item. Those students with logit measure higher than 1,39 are categorized into high level students, and those students whose logit measure fall between 1,30 and $-3,11$ are considered as students with moderate level of speaking ability, and those whose logit measure fall below $-3,11$ are categorized as students with low level of speaking ability.

As shown in the table above, the majority of the students (71\%) perceived themselves as having moderate level of speaking ability, followed by $16 \%$ of them who perceived as having moderate level of speaking ability and only $12 \%$ of them who identified themselves as having high level of Arabic language speaking ability.

The finding of this study was in line with the previous research carried out by Anandi. ${ }^{12}$ She also found that majority of the students rated themselves as having moderate level of Arabic language speaking ability. Meaning that they still need to improve some aspects in speaking skills, for instance, they have to improve their vocabulary and their understanding about the topics they're going to deliver or talk about.

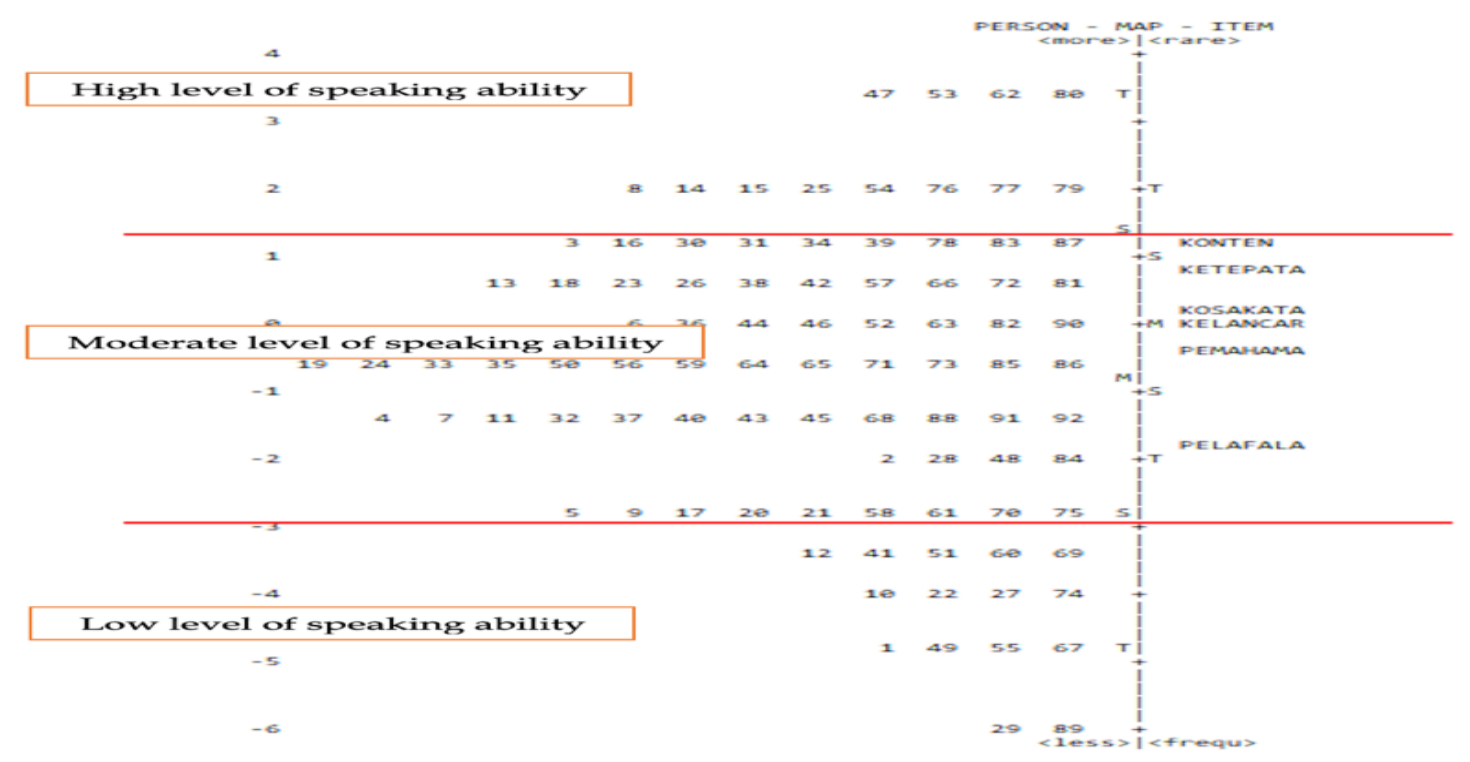

Figure 1. Person and Item Map

12Rizki Parahita Anandi, 'Analysis of Rater Severity on Students' Arabic Language Speaking Assessment'. 
The left side of the Person and Item Map above illustrated the distribution of students based on their self-assessment of speaking skill. The higher the students' position on the map, the higher they rated their speaking ability. ${ }^{13}$ As shown on the map, students number 47, 53, 62 and 80 are among those who perceived themselves as high ability students. Those 4 students are male students and they have experienced learning Arabic in pondok (Islamic boarding school) before attending university. The study conducted by Anandi also revealed that previous experience in learning the Arabic language have a positive impact on their speaking ability. ${ }^{14}$

On the other hand, students number 29 and 89 are those who identified their ability as moderate level. Student number 29 is a female student and student number 89 is a male student and both have experienced living and learning Arabic in pondok.

In conclusion, majority of the students perceived their Arabic speaking ability as moderate level. Meaning that they still need to improve some aspect of speaking skill that they found it difficult, for example the accuracy in using grammatical rule and the mastery of content. Lecturers can start teaching their students about selfassessment because it can help them reflect their performance and improve their learning.

\section{Students' Self-Assessment of Speaking Ability Based on Demoghrapic Background}

There are six aspect of speaking skills that used to measure students' ability, they are pronunciation, accuracy, vocabulary, content, fluency and comprehension and strategic competence.

Table 4. Logit Measure of Self-Assessment Rubric Item Difficulty Category

\begin{tabular}{cccc}
\hline Logit Score & Number of Item & Percentage & Level \\
\hline$>0,95$ & 1 & $17 \%$ & Difficult \\
\hline $0,00-0,95$ & 4 & $66 \%$ & Medium \\
\hline$<-0,95$ & 1 & $17 \%$ & Easy \\
\hline
\end{tabular}

${ }^{13}$ Benjamin D Wright and Mark H Stone, 'Measurement Essentials', Measurement, 1999, 205.

${ }^{14}$ Rizki Parahita Anandi, 'Anxiety in Speaking Arabic Language Among University Students in Central Java', 2018. 
The Person and Item Map displayed the hierarchy of those six aspects based on its difficulty as rated by the students. It can be seen from the figure below:

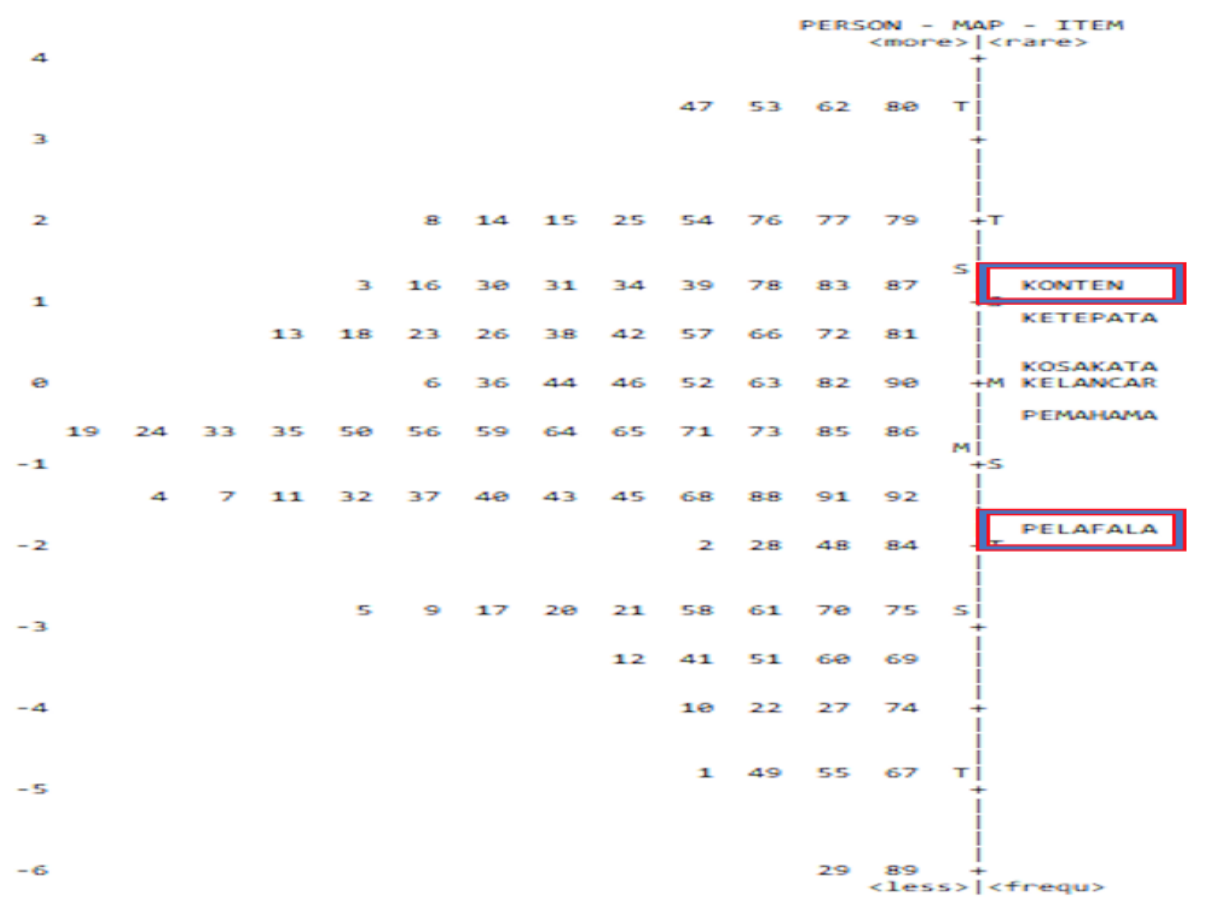

Figure 2. Person and Item Map

The content, with the logit measure 1,27, was rated as the most difficult aspect of speaking. Followed by accuracy $(0,72)$, vocabulary $(0,13)$, fluency $(0,05)$, comprehension and strategic competence $(-0,40)$, and pronunciation $(-1,77)$. This indicated that the students perceived mastering the content was the most difficult aspect of speaking. While the easiest aspect of speaking was pronunciation.

Other studies also revealed that pronunciation was the easiest part of speaking. ${ }^{15}$ This might happen because Indonesian are already familiar with Arabic pronunciation, since they perform prayer in Arabic as well as reading the Holy Qur'an, which is also written in Arabic language. ${ }^{16}$

Since the accuracy in using grammatical rule was rated as the most difficult aspect of speaking by the students of IAIN Salatiga, they need to evaluate their

\footnotetext{
${ }^{15}$ Wulida Wahidatul Masruria, 'Exploring Self-Assessment of Speaking Skill By Efl High School Students', English Education and Art (LEEA) Journal, 4.23 (2021), 2597-3819.

${ }^{16}$ Anandi, 'Analysis of Rater Severity on Students' Arabic Language Speaking Assessment'.
} 
learning strategy and reflect on it or seek help from their peers or lecturers. Mastering grammatical rule, which is categorized into language competence, may affect students' speaking performance. ${ }^{17}$ Therefore, students and lecturers should design learning strategy to improve students' grammatical rules, besides they also need to improve other aspects of speaking skill.

On the other hand, some previous studies showed different result, for instance the study conducted by Anandi who found that mastering Arabic vocabulary was the most difficult aspect of speaking, while accuracy was identified as the easiest one. ${ }^{18}$

The finding of this Wright Map can give further information for the Arabic language lecturers about what skills do students need to improve. As illustrated in the map above, students reported that mastering the content of discussion or speaking activity is the most difficult skill, therefore lecturers need to find the strategy or classroom activity that can help students to improve it. Besides, the other five skills are also need to be improved.

Babaii, Taghaddomi and Pashmforoosh added that self-assessment may increase their self-awareness and detect their weak points. ${ }^{19}$ It also gave a chance to the students to identify their own performance based on the aspects mentioned in the rubric. So, as mentioned by Ariafar and Fatemipour, they will be able to reflect on their performance and get an insight about what they have to improve to make their speaking performance better. ${ }^{20}$ Besides, they can be more responsible for their own learning process. For instance, for those who rated that content was the most difficult aspect to master, they would know that they should read more articles or books related to the various topics. While those who identified that the accuracy of

\footnotetext{
${ }^{17}$ Husnawati, 'Student's Speaking Performance: Some Challenging Factors', Journal of Universitas Islam Negeri AR-Raniry Darussalam Banda Aceh, 8.9 (2017), 80.

${ }^{18}$ Rizki Parahita Anandi, 'Analysis of Rater Severity on Students' Arabic Language Speaking Assessment'.

${ }^{19}$ Esmat Babaii, Shahin Taghaddomi, and Roya Pashmforoosh, 'Speaking Self-Assessment: Mismatches between Learners' and Teachers' Criteria', Language Testing, 33.3 (2016).

${ }^{20}$ Mahsa Ariafar and Hamid Reza Fatemipour, 'The Effect of Self-Assessment on Iranian EFL Learners' Speaking Skill', International Journal of Applied Linguistics and English Literature, 2.4 (2013), 7-13.
} 
using grammatical as the most difficult aspect, they would need to practice more on using grammatical rules.

\section{CONCLUSION}

This survey research revealed that the majority of the Arabic Education Department students in IAIN Salatiga perceived themselves as having moderate level of speaking ability. It showed that they still need to improve their speaking skills such as mastering the content they will deliver as well has mastering the accuracy in using grammatical rules when they speak using Arabic language. The wright map described that the students' ability in understanding the content still need to be improved. Students can put their effort more on reading different themes so that they will get more vocabularies and insight about many new topics. Besides, the teacher can also help their students to improve their speaking ability by designing materials and classroom activities that focus on specific aspects.

Further investigation should be carried out to explore more about the students' perception on their learning activities and achievement. While for foreign language lecturers, the finding of this study can be used to evaluate the learning strategy, material and curriculum. The lecturers can also use the speaking rubric to assess their students' performance at the very first meeting so that they will get initial information about the students' ability.

\section{REFERENCE}

Anandi, Rizki Parahita, 'Analysis of Rater Severity on Students' Arabic Language Speaking Assessment'

- - , 'Anxiety in Speaking Arabic Language Among University Students in Central Java'. Thesis of Faculty of Education', 2018

Ariafar, Mahsa, and Hamid Reza Fatemipour, 'The Effect of Self-Assessment on Iranian EFL Learners' Speaking Skill', International Journal of Applied Linguistics and English Literature, 2.4 (2013), 7-13.

Asdar, 'Students ' Self -Assessment on Their Spoken Interaction Using Cefr', The 1st Education and Language International Conference Proceedings Center for International 
Language Development of Unissula, 2017, 148-61.

Babaii, Esmat, Shahin Taghaddomi, and Roya Pashmforoosh, 'Speaking SelfAssessment: Mismatches between Learners' and Teachers' Criteria', Language Testing, 33.3 (2016), 411-37.

Butler, Yuko Goto, and Jiyoon Lee, 'The Effects of Self-Assessment among Young Learners of English', Language Testing, 27.1 (2010), 5-31.

Correia, Rúben Constantino, 'Assessing Speaking Proficiency: A Challenge for the Portuguese EFL Teacher', E-TEALS, 7.1 (2016), 87-107.

Dickinson, Leslie, Self-Instruction in Language Learning, Angewandte Chemie International Edition, 6(11), 951-952. (Australia: Press Syndicate of the University of Cambridge, 1987)

Eaton, Sarah Elaine, Global Trends in Language Learning in the 21st Century, Onate Press (Calgary, 2010)

Hati, Gita Mutiara, Wisma Yunita, and Anggun Citra Sari Dewi, 'Self Assessment for Higher Language Learners' Autonomy', JOALL (Journal of Applied Linguistics and Literature), 6.2 (2021), 264-76.

Husnawati, 'Student's Speaking Performance: Some Challenging Factors', Journal of Universitas Islam Negeri AR-Raniry Darussalam Banda Aceh, 8.9 (2017), 80.

Kaharuddin, Kaharuddin, ‘Pembelajaran Bahasa Arab Melalui Kemampuan Muhadatsah', AL-ISHLAH: Jurnal Pendidikan Islam, 16.1 (2018), 62-72.

Masruria, Wulida Wahidatul, 'Exploring Self-Assessment of Speaking Skill By Efl High School Students', English Education and Art (LEEA) Journal, 4.23 (2021), 2597-3819.

Montgomery, Cherice, Speaking Rubric by Bill Heller, 2000

Rahmawati, Yenny., and Ertin, 'DEVELOPING ASSESSMENT FOR SPEAKING Yenny Rahmawati \& Ertin', Indonesian Journal of English Education, 1 (2014), 199210

Ross, John A., 'The Reliability, Validity, and Utility of Self-Assessment', Practical Assessment, Research and Evaluation, 11.10 (2006)

Wright, Benjamin D, and Mark H Stone, 'Measurement Essentials', Measurement, 1999,205 